\title{
Is it possible to eliminate hepatitis $C$ from the prisons of Catalonia, Spain, in 2021?
}

\author{
Marco A ${ }^{1,2}$, Guerrero RA ${ }^{1}$, Turu E ${ }^{1}$, Gallego $C^{3}$, Teixidó $N^{4}$, Sastre A ${ }^{5}$, \\ Caylà JA ${ }^{2,6}$ y GRUMIP* (GRUMIP or Grup de Control \\ de Malalties Infeccioses en el Àmbit Penitenciari)
}

\author{
${ }^{1}$ Prison Health Programme. Catalonian Health Institute \\ ${ }^{2}$ Centre for Biomedical Research on the Epidemiology and Public Health Network (Centro de Investigación \\ Biomédica en Red de Epidemiología y Salud Pública (CIBERESP)) \\ ${ }^{3}$ Primary Prison Healthcare Team of Roca del Vallés-1, Barcelona \\ ${ }^{4}$ Primary Prison Healthcare Team of Sant Esteve Sesrovires-1, Barcelona \\ ${ }^{5}$ Primary Prison Healthcare Team of Sant Esteve Sesrovires-2, Barcelona \\ ${ }^{6}$ Epidemiology Service. Public Health Agency of Barcelona
}

\begin{abstract}
Aim: Predict the elimination of chronic hepatitis $\mathrm{C}$ in Catalan prisons.

Material and method: We analyzed the trend of the prevalence of HCV-RNA and anti-hepatitis C treatments prescribed in Catalonia in the period 2002-2016. Using linear exponential smoothing from the historical values in the time series, we estimate the time required to eliminate hepatitis $\mathrm{C}$ as a public health problem in prisons (prevalence of hepatitis $\mathrm{C}$ virus $\mathrm{RNA}<1 \%$ ).

Results: A total of 1264 treatments were administered by 12/31/2016. The prevalence of hepatitis C virus RNA was $31.2 \%$ in 2002, decreasing to $8.81 \%$ in 2016 . We estimate that prevalence will reach $0-0.5 \%$ in 5 years (second half 2021 ; $95 \%$ CI: 2019 2025).

Discussion: Appropriate actions can eliminate hepatitis C infection in prisoners. We estimate that by 2021 hepatitis $\mathrm{C}$ infection will no longer be a public health problem in Catalonia prisons.
\end{abstract}

Keywords: hepatitis C, disease eradication, prisons, time series studies, epidemiology.

Text received: 29/01/2018

Text accepted: $17 / 07 / 2018$

\section{INTRODUCTION}

Catalonia is the only autonomous community that has powers with regard to prisons and that, along with the Basque Country, has transferred prison healthcare to the regional health authorities. It currently has 7.5 million inhabitants and nine prisons. In 2016, there were 14,137 persons in prison, which means a ratio of the inmate population of 130.5 per 100,000 inhabitants ${ }^{1}$. Healthcare of the inmates is similar to that of the population outside prison, due to the fact that in the 80s, the severe problem of infections associated with drug use
(HIV infection, tuberculosis, viral hepatitis, etc.) led to the creation or improvements in nursing units in prisons, and with that, doctors with expertise in infectious diseases are available. In 2002, when the prevalence of infection by $\mathrm{HCV}$ was at $40 \%{ }^{1}$, a Prison Hepatitis Programme was implemented in order to prevent transmission, diagnose infection and treat infected patients with indicated therapies. These aims have not changed, but now the main objective, in line with the Global Health Sector Strategy on Viral Hepatitis of the World Health Organisation $(\mathrm{WHO})^{2}$, is to eliminate the infection or reduce it, so that it is no longer an epidemic hazard. 
The aim of this study is to predict with time series analysis when HCV could be eliminated or no longer be a public health problem in Catalonian prisons.

\section{MATERIALS AND METHODS}

The prevalence of HCV infection amongst inmates in Catalonia by yearly periods was collected using universal screening, along with the number of treatments for hepatitis C carried out in the period 20022016. From 2002 to September 2014, treatments used pegylated interferon $\alpha 2 \mathrm{~b}(1,5 \mu \mathrm{g} / \mathrm{kg} /$ week $)$ or $\alpha 2 \mathrm{a}$ $(180 \mu \mathrm{g} /$ week $)$ plus ribavirin $(\mathrm{PegINF}+\mathrm{RBV})$, in line with standard recommendations. From 2013 to September 2014, boceprevir (BOC) or telaprevir (TPV) was added to PegINF+RBV in cases with genotype 1, while in those patients infected with other genotypes, the aforementioned bi-therapy continued to be used. Finally, since 2015, only combined direct-acting antiviral agents (DAA) without interferon have been used.

The computerised clinical history was checked, and the following data of the treated patients was gathered: age, sex, record of intravenous drug use (IDU), HIV serology, HCV genotype, sustained virological response (SVR) and discontinuation or not of treatment. The SVR was defined as undetectable HCV-RNA (Cobas ${ }^{\circledR}$ Amplicor HCV Test v2.0, Roche Diagnostic Systems, Barcelona, Spain) 24 or 12 weeks after compliance with treatment, in line with the recommendations applied in the time period in which the prescription was made. The analysis of the SVR and discontinuation of treatment was carried using intention to treat (ITT; loss = failure) and by treatment observed. The following information was used for sources: the computerised clinical history, the health descriptors of prison statistical system of the Regional Government of Catalonia1 and the data bases of the Healthcare Department of the Department of Justice and, from 1 October 2014, from the Prison Health Program of the Catalonian Health Institute (Programa de Salud Penitenciaria del Institut Català de la Salut (ICS)). In view of the lack of definition, "elimination as health public health problem" was regarded as a reduction in the prevalence of HCV RNA to below $1 \%$. As there was no data published on the prevalence of infection in the first years, the HCV RNA was calculated at $78 \%$ of the serology value of anti-HCV antibodies.
The linear exponential smoothing method of historical values of the time series was used to estimate the time that would be required, including all the inmates in the treatment, independently of the degree of fibrosis, and maintaining the current treatment trend, to eliminate chronic hepatitis $\mathrm{C}$ as a public health problem (prevalence of HCV RNA<1\%) amongst Catalonian prisoners, calculating the confidence interval at $95 \%$. A future efficacy equal to or greater than $95 \%^{3}$ was estimated for the prediction, along with a discontinuation below $3 \%{ }^{3}$ and a global re-infection rate of 2.39 per 100 patients per year of monitoring ${ }^{4}$.

The study was carried out in accordance with international ethical recommendations (Helsinki Declaration and Oviedo Convention), the laws of Best Clinical Practices, R.D. 711/2002, and current Spanish legislation (Circular 15/2002).

\section{RESULTS}

1,264 anti-hepatitis $C$ treatments had been prescribed up to 31 December 2016:

- 872 PegINF+RBV.

- 43 with PegINF+RBV plus BOC or TPV.

- 349 with DAA.

The patients treated with DAA presented:

- Greater average age (45+/-6.7 years compared to $36.3+/-7.1$ years for those treated with other therapies; $\mathrm{p}=0.002$ ).

- More frequently, co-infection with HIV (49.5\% compared to $28.5 \%$; $\mathrm{p}<0.001$ ).

- More frequent genotype $1(63.8 \%$ compared to $46.8 \% ; \mathrm{p}<0.001)$, but without significant differences with regard to sex $(97.3 \%$ of men with DAA compared to $95.4 \%$ with other treatments; $\mathrm{p}=0.23$ ) or with regard to background of IDU $(79.8 \%$ with DAA compared to $74.6 \%$ with other treatments; $\mathrm{p}=0.17$ ).

With ITT analysis, the SVR was $62 \%$ with PegINF+RBV, of the $65.1 \%$ with BOC or TPV plus PegIN$\mathrm{F}+\mathrm{RBV}$, and $93.6 \%$ with DAA $(\mathrm{p}<0.001)$. Using analysis of observed treatment, the SVR was $76.5 \%$, $87.5 \%$ and $97.2 \%$, respectively $(\mathrm{p}<0.001)$. Discontinuation of treatment was:

- $18.9 \%$, in patients treated with PegINF+RBV.

- $25.6 \%$, in patients treated with BOC or TPV plus PegINF+RBV.

- $3.7 \%$, in patients treated with DAA $(\mathrm{p}<0.001)$. 
There was also lower discontinuation of treatment due to release from prison in patients treated with DAA (1.6\% compared to $7.1 \%$; $=0.001)$.

The prevalence of HCV RNA was reduced, in the period 2002-2016 (Figure 1), $71.7 \%$ (from $31.2 \%$ to $8.81 \% ; \mathrm{p}<0.001)$. This prevalence shall continue to drop in subsequent years and will be $7.2 \%, 5.6 \%, 4 \%$, $2.3 \%$ and $1.2 \%$ in 2017, 2018, 2019, 2020 and 2021, respectively. It is estimated that prevalence shall reach $0-0.5 \%$ in the second half of 2021 (CI of $95 \%$ : 20192025).

\section{DISCUSSION}

According to the data consulted to carry out this study, only the United Kingdom Prison Administration has calculated the time necessary to eliminate hepatitis $\mathrm{C}$ from amongst its prisoners, and it estimates that it will not be possible until at least $2030^{5}$. As this study shows, with a prediction based on therapeutic and diagnostic time series analysis of 15 years, amongst inmates in Catalonia, eliminating hepatitis $\mathrm{C}$ so that it does not imply a serious risk to public health is an objective that can be reached in five years, which is a timescale that complies with the objectives set out by the WHO. This data differs considerably from that of the Spanish population outside prison, where it is estimated that in order to eliminate hepatitis $\mathrm{C}$ in double the period (in ten years), it is necessary to improve detection of prevalent undiagnosed cases of this disease and increase access to treatment for infected cases without fibrosis or with degrees of early fibrosis, which was not authorised at the time.

The prediction calculated for inmates in Catalonia is highly satisfactory, and is probably due to the type of monitoring and control programme for $\mathrm{C}$ used in the region, which is based on:

- The prevention of transmission of the infection by using treatment programmes with opioid ago-

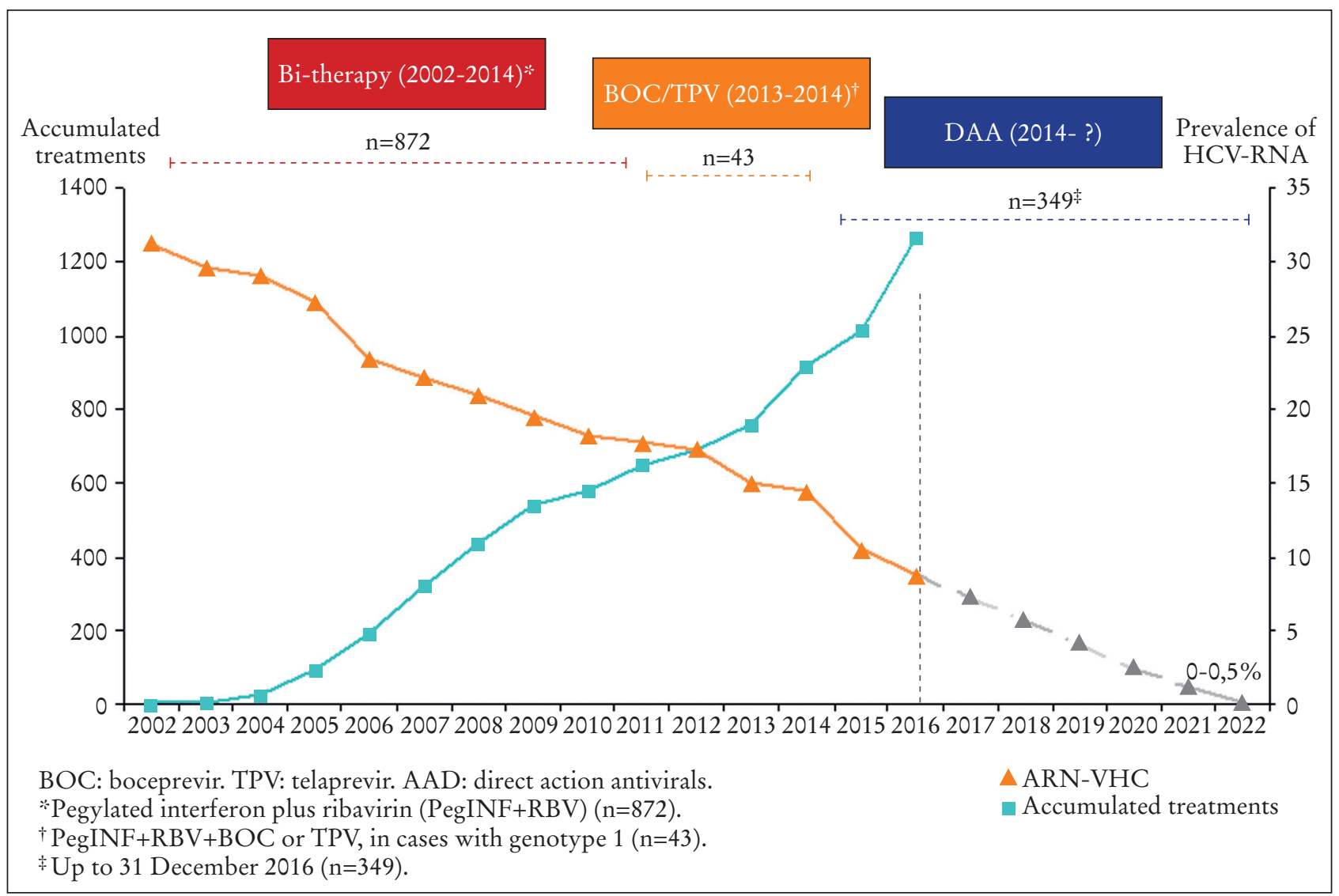

Figure 1. Observed prevalence of HCV-RNA (2002-2016), accumulated treatments of hepatitis C up to 2016, and estimated prevalence of HCV-RNA (2017-2022) in Catalonian prisons. 
nists (OAT), and the widespread application of needle administration in its prisons.

- The use of universal screening to diagnose hidden infection.

- Access to treatment for prisoners under similar conditions to those for infected persons not in prison.

The OATS and dispensation of sterile injection materials are effective preventive strategies for preventing transmission of HIV and hepatitis $\mathrm{C}$ amongst users of opioids, but many countries do not have OATs in prisons, and only 70 of the $10,000+$ prisons worldwide offer injection materials ${ }^{7}$. Universal screening for detecting infection is not very widespread in prisons in many high income countries either.

As regards access by inmates to treatment of hepatitis $\mathrm{C}$, there have been some important limitations. The prison health systems should ideally function in line with the principles of equality and equivalence; in other words, inmates should have access to health services that are of a similar quality to those in the community, and that this should continue of if the inmate is released. According to the available evidence, there is no medical reason to justify limiting access to treatment of hepatitis $C$ for prisoners. Such discrimination, where it exists, infringes the rights of inmates to health and is also a strategic error, since treatment of inmates is essential to hold back the epidemic of C8 and limiting it has a negative economic impact ${ }^{8}$. Prisons are ideal places to apply treatment, and can make a major contribution to the country in controlling infection at a community environment level. To sum up, with firm policies, programmed organisation and social commitment, hepatitis $\mathrm{C}$ can be eliminated from prisons. If this is possible, then the sooner it is done, the better.

\section{CORRESPONDENCE}

Andrés Marco

Enfermedades Infecciosas

Programa de Salud Penitenciaria

Gran Vía de les Corts Catalanes, 587-589

Barcelona 08007

E-Mail:amarco@gencat.cat

andres.marco.m@gmail.com

\section{REFERENCES}

1. Departament de Justícia. Descriptors estadístics serveis penitenciaris. [Internet; fecha de acceso: 18 Mar 2017]. Disponible en: http://www.gencat.cat/justicia/estadistiques_serveis_penitenciaris/1_pob.html

2. Organización Mundial de la Salud. Estrategia mundial del sector de la salud contra las hepatitis víricas 20162021. [fecha de acceso: 8 May 2017]. Disponible en: http://apps.who.int/iris/bitstream/10665/250578/1/ WHO-HIV-2016.06-spa.pdf

3. Marco A, Roget M, Cervantes M, Forné M, Planella R, Miquel M, et al. Comparison of effectiveness and discontinuation of interferon-free therapy for hepatitis $\mathrm{C}$ in prison inmates and noninmates. J Viral Hepat. 2018;25:1280-6.

4. Marco-Mouriño A, Guerrero RA, Turu E, GRUMIP. Eficacia, discontinuación y tasa de reinfección post respuesta viral sostenida tras 15 años (2002-2016) de tratamiento de la hepatitis C crónica en reclusos de Cataluña. Rev Esp Sanid Penit. 2018;(20 Suppl 2):79.

5. Gelson W, Alexander G. Is elimination of hepatitis C from the UK by 2030 a realistic goal? $\mathrm{Br}$ Med Bull. 2017;123:59-67.

6. Buti M, Calleja JL, García-Samaniego J, Serra MA, Crespo J, Romero M, et al. Eliminación de la hepatitis $C$ en España: adaptación de un modelo matemático de Salud Pública partiendo del plan estratégico para el abordaje de la hepatitis C en el Sistema Nacional de Salud. Med Clin (Barc). 2017;148:277-82.

7. Kastelic A, Pont J, Stöver H. Opioid Substitution Treatment in Custodial Settings. A Practical Guide. World Health Organization. United Nations. BIS-Verlag der Carl von Ossietzky Universität Oldenburg. [fecha de acceso: 7 Jun 2017]. Disponible en: https://www.unodc.org/documents/ hiv-aids/OST_in_Custodial_Settings.pdf

8. Marco A, Domínguez-Hernández R, Casado MA. Análisis coste-efectividad del tratamiento de la hepatitis C crónica en población reclusa. Rev Esp Sanid Penit. 2018;(20 Suppl 2):82. 